Research Square
Preprints are preliminary reports that have not undergone peer review.

They should not be considered conclusive, used to inform clinical practice, or referenced by the media as validated information.

\title{
Impact of Covid-19 pandemic on Prevalence of complaints related to violence against women in India - A cross-sectional comparative research study from 2014 to 2022 ?
}

Dr Piyush Kumar ( $\nabla$ drpiyush003@gmail.com)

Bihar Health Services- Government of Bihar, India https://orcid.org/0000-0001-9857-478X

Advocate Anupama ( $\square$ advocateanupama007@gmail.com )

Bar Council, Patna, Bihar, India https://orcid.org/0000-0003-3651-2705

\section{Research Article}

Keywords: Covid, pandemic, violence, women, lockdown, domestic abuse

Posted Date: February 14th, 2022

DOI: https://doi.org/10.21203/rs.3.rs-1357110/v1

License: (c) (1) This work is licensed under a Creative Commons Attribution 4.0 International License. Read Full License

Version of Record: A version of this preprint was published at CrimRxiv on February 16th, 2022. See the published version at https://doi.org/10.21428/cb6ab371.9ad5ab9e. 


\section{Abstract}

Violence against women is a global problem, affecting women around the world irrespective of age, races, education, ethnicity, groups, economy classes and nationalities. Sometimes in situation of disaster like covid-19 pandemic it may be a life-threatening situation for an individual woman. In India due to a huge female population, illiteracy, equity issues, gender issues, religious issues, lack of positive deviance, illiteracy, socio-economic factors, migration after marriage and in search of job from rural to urban areas, inaccessibility to seek legal help, the safety of women is of prime concern. The key aim of this observational retrospective cross-sectional comparative mixed research study is to find out impact of SARS-CoV-2/Covid-19 Pandemic era on Prevalence of complaints of violence against women in India, across 36 different states and union territories from the beginning of the pandemic i.e. January 2020 and comparing it with previous six pre-pandemic years. The objective is to find out that the ongoing covid-19 pandemic years has a positive or negative effect over prevalence of complaints of violence against women. Data from NCW (National Commission for Women) which set up by Act No. 20 of 1990 of Govt. of India as constitutional/ legislative body in January 1992 under the (National Commission for Women) NCW Act, 1990, is extracted, observed, analysed for this research study with Microsoft office and stata software. The period of study is from January 2014 to 2022 December (projected). This is an observational retrospective cross-sectional comparative mixed research study. The ongoing three years of covid-19 pandemic i.e. 2020 and 2021,2022 is compared to previous pre-pandemic years to know the impact of covid-19 on complaints of violence against women in India. Increase in prevalence of complaint of violence against women in India is revealed in this research study during covid-19 pandemic years as compared to pre-pandemic era under observation except 2014. During the 2021, second year of covid-19 pandemic the total numbers of violence complaint Report of the Complaints Received by NCW was 30865 which is an increase by $\mathbf{5 5 . 0 3}$ percent compared to $\mathbf{2 0 1 8}$ and $\mathbf{5 6 . 4 3 \%}$ as compared to $\mathbf{2 0 1 9}$. This research study found that National Commission for Women is expected to receive 35287 complaints of crimes committed against women in 2022 as per current trends, the highest in the last eight years. The barriers in delivery of legal and protective system and helpful services etc. should be rectified. A proper dynamic plan for women protection services working even in pandemics and natural disasters should be enforced and implemented.

\section{Introduction}

\section{Background / rationale}

Violence against women is a global problem, affecting women around the world irrespective of age, races, education, ethnicity, groups, economy classes and nationalities [1]. Sometimes in situation of disaster like covid-19 pandemic it may be a life-threatening situation for an individual woman. In India due to a huge female population, illiteracy, equity issues, gender issues, religious issues, lack of positive deviance, illiteracy, socio-economic factors, migration in search of job from rural to urban areas, inaccessibility to seek legal help, the safety of women is of prime concern. The SARS-CoV-2 led ongoing pandemic had presented a challenge to women safety even for developed nations as well as LMICs (low and middle income countries) like India [2]. Violence is a burden of social system and affects the progress of a nation. It affects nations income in terms of health provision, law enforcement, DALYs (disability adjusted life years) and overall progress in development [3]. The violence based on gender discrimination is usually inflicted upon a female on the basis of her sex. Act of violence includes multiple acts like physical, mental, social, or sexual harm [3]. Such acts may have adverse effect on health status of a woman, her productivity, belief of self- esteem, sufficiency, confidence as well as overall quality of life.

The global burden of violence against women estimated by WHO states that globally about 1 in 3 (30\%) of women have encountered either physical and/or sexual abuse or non-partner sexual violence during their lifespan. The enforcement and implementation of lockdowns to control the COVID-19 has social and economic impacts [4]. This may have increased the exposure of females to abusive inmates and restricting their access to protective services. This is a situation of humanitarian crises and displacement due to covid-19 which may increase existing violence, as well as other-partner sexual violence, leading to increase of violence against women [5].

Domestic abuse/domestic violence or intimate partner violence is defined as the act/type of behaviour in any relationship used to gain power and control over an intimate partner which may be directed physically, sexually, emotionally, economically or psychologically or threats of activities that can influence another person. These acts include any kind of behaviour causing frightening, intimidating, terrorizing, manipulating, hurting, humiliating, blaming, injuring, or wounding someone[6]. Domestic abuse can happen to anyone of any race, age, ethnicity, sexual orientation, religion, or gender. This can occur in different range of relationships including married couples, living together or dating. Domestic violence/abuse can affects people of all socioeconomic-strata backgrounds and education levels [5].

WHO has made the assessment stated in WHO Director-General's- Dr Tedros opening remarks at the media briefing on COVID-19-11 March 2020 that COVID19 can be characterized as a pandemic [7]. India has reported first covid-19 case in January 2020 (hence author is considering period up to December 2019 as pre-pandemic era for India) [8]. The women and children are special vulnerable group [9].

\section{Objectives}

The key objective of this observational research study is to know impact of SARS-CoV-2/Covid-19 ongoing Pandemic years on prevalence of complaints of violence against women in India across 36 states and union territories from the beginning of pandemic due to covid-19 i.e. January2020 by comparing the observation with pre- pandemic years. The author hypothesise that lockdown and stressful situation arising from the constraints of ongoing covid-19 pandemic can increase the prevalence of domestic violence is also evaluated from the data.

\section{Methods}

\section{Study Design}


This is an observational retrospective cross-sectional comparative mixed research study. Data from January2014 to January 2022 is taken for this observational research study in order to have a comparative analysis of third years of pandemic era i.e. 2020 and 2021,2022 (data for January 2022 is available and forecasted up to December 2022 with previous data of pandemic era i.e. 2020-2021- Jan 2022) with pre-pandemic years i.e., 2014, 2015, 2016, 2017, 2018, 2019.

\section{Setting}

Data from NCW (National Commission for Women) which set up by Act No. 20 of 1990 of Govt. of India as constitutional/ legislative body in January 1992 under the (National Commission for Women) NCW Act, 1990, is extracted, observed, analysed for this research study with Microsoft office and stata software. The period of study is from January 2014 to 2022 December (projected).

\section{Locations}

All 36 different states and union territories in India are included in this research study.

\section{Relevant dates}

The exact period of study is 1 st January2014 to 31 st December 2022 (projected with excel software)

\section{Exposure}

Any complain of violence against women in India, across 36 different states and union territories exposed to following types of violence and reported it to NCW, India is included in this research study (see table -1 below) 


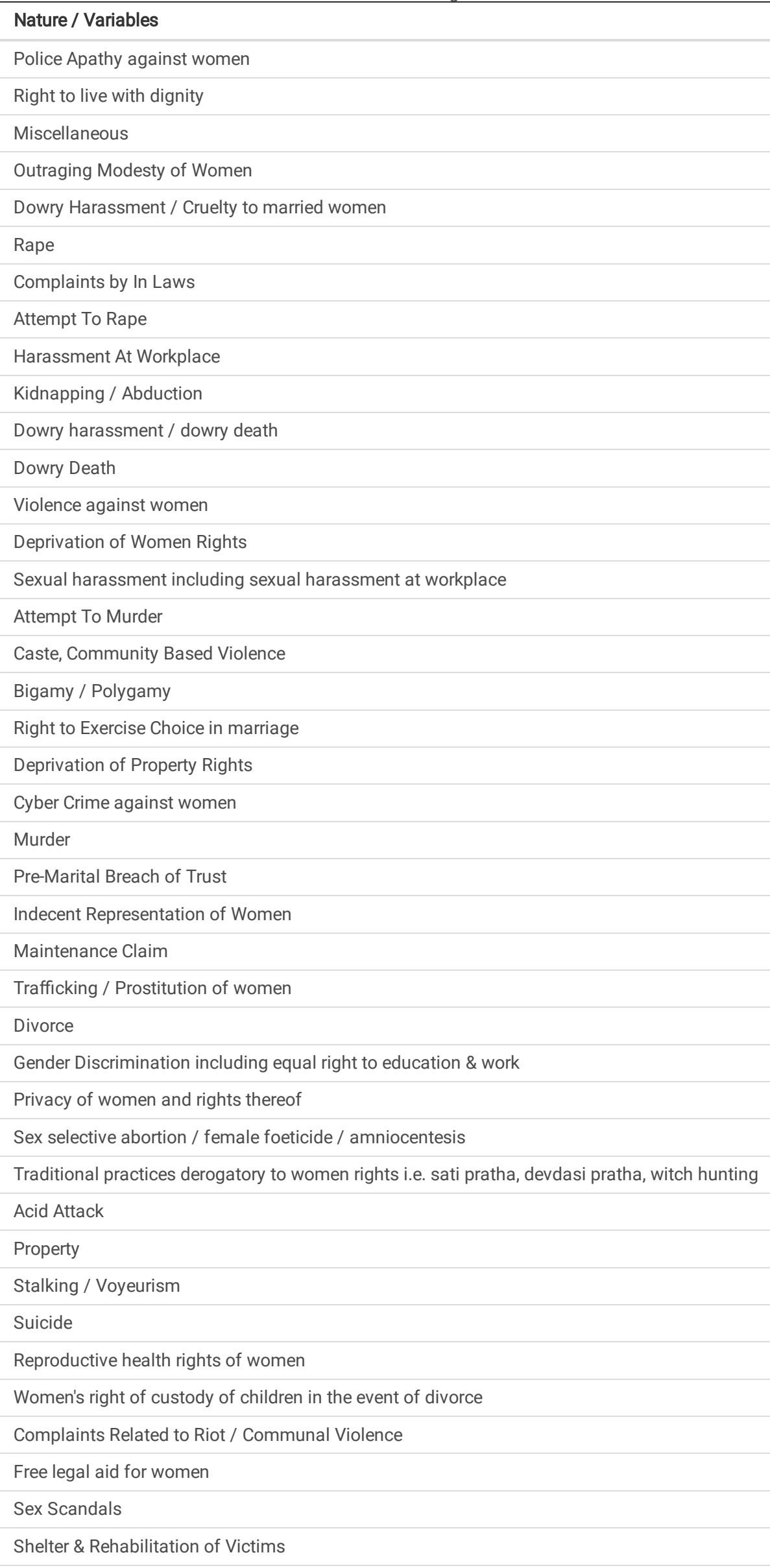




\begin{tabular}{|l|}
\hline Nature / Variables \\
\hline Harassment \\
\hline
\end{tabular}

Follow-up and data collection

The data is collected continuously and repeatedly investigated for specificity, accuracy, measurability, timeliness, reproducibility from electronic source of accredited National commission for women, India in this research study. The nature-wise data indicating complaints registered with National Commission for Women in India (NCW) under different categories were collected-analysed with Microsoft office and stata software. The period of study is from 1 st January 2014 to 31 st December 2022 (projected with data of pandemic years 2020, 2021and Jan 2022). The data is compared to pre-pandemic years. The ongoing three years of covid-19 pandemic i.e. 2020 and 2021, 2022 is compared to previous pre-pandemic years to know the impact of covid-19 on complaints of violence against women in India.

\section{Participants}

Eligibility criteria

All the female population residing in India of all ages (data is taken from World Bank) in different years of study.

Sources and method of selection

Assuming that the whole female population across India have actively participated in reporting violence against them to NCW purposive sampling is done to know the number of complaints registered with NCW. The author admits that India being a LMICs (low and middle income countries) there may be huge underreporting due to lack of knowledge of the process of reporting, illiteracy, inaccessibility and other factors like socio-economic factors and different barriers of communications to report the complaint.

\section{Variables}

The variables studied in this research study are listed in table-1.

\section{Data Availability}

Data Sources

The data for number of complaints of violence against women is collected from electronic records of NCW. The female population data is collected from electronic records of World Bank. A link for the data source is available below:

http://ncwapps.nic.in/frmComp_stat_Overview.aspx - NCW

https://data.worldbank.org/indicator/SP.POP.TOTL.FE.ZS?locations=IN - The world Bank- for female population data- projected up to 2022 with previous data using excel

For comparative analysis the total of all the violence complaints registered with NCW is taken to avoid discrepancies in different nature of crimes as some new entities are added whereas some are removed or added to some other categories of crime in different years.

Data Analysis / Measurements

The analysis is done with Microsoft office and stata software.

Bias

To address bias in the study the data available is forecasted with the help of Microsoft office and stata software.

Study Size

The period of study is from 1st January 2014 to 31st December 2022(projected with data of pandemic years 2020, 2021and Jan 2022). All the female population living in India of all ages (data is taken from World Bank) in different years of study. Since this research study is observing only violence complaints against women the female (all ages) population of India is taken for the study and the most accredited, latest available data sources mentioned above is taken for the study.

\section{Missing Data}

The data of variable which is not categorised yet reported in January 2022 is considered as mean for all the consecutive months.

\section{Results}

For the year 2014 the total number of numbers potentially eligible females included in this research study was 621852998 in number, whereas for the years $2015,2016,2017,2018,2019,2020,2021$ (forecast) and 2022(forecast) it was 628929060, 635912563, 642796257, 649586703, 656288184, 656288184, 670890572.9 , and 679672034.8 respectively (see table-2). These numbers mentioned above represents the total female population of India in different years across 36 states and union territories. The source of female population data is the World Bank and for the year 2021 and 2022 the population is forecasted 
with the help of Microsoft excels utilizing available data of previous years since 1960. For each variable the data available with NCW is compared with same variable of previous years.

This research study found that National Commission for Women is expected to receive 35287 complaints of crimes committed against women in 2022 as per current trends, the highest in the last eight years. The total numbers of Nature-Wise Report of the Complaints Received by NCW in the Year: 2014 was 33906 whereas it reduced during 2015 during which it was 23370. The total numbers of Nature-Wise Report of the Complaints Received by NCW in the Year: 2016, $2017,2018,2019,2020,2021,2022$ (forecast) is $19088,14591,19908,19730,23722,30865,35287$ respectively (table-1, Fig. 1).

Table-1- total numbers of complaints of violence against women received by NCW in different Year

\begin{tabular}{|llll|}
\hline Year & $\begin{array}{l}\text { Total numbers of } \\
\text { complaints }\end{array}$ & $\begin{array}{l}\text { Increase or Decrease in number compared to previous } \\
\text { year }\end{array}$ & $\begin{array}{l}\text { Percent Increase or Decrease compared to previous } \\
\text { year }\end{array}$ \\
\hline 2014 & 33906 & Study started & Study start year \\
\hline 2015 & 23370 & 10536 decrease & $31.0741 \%$ decrease \\
\hline 2016 & 19088 & 4282 decrease & $18.3226 \%$ decrease \\
\hline 2017 & 14591 & 4497 decrease & $23.5593 \%$ decrease \\
\hline 2018 & 19908 & 5317 increase & $36.44027 \%$ increase \\
\hline 2019 & 19730 & 178 decrease & $0.89411 \%$ decrease \\
\hline 2020 & 23722 & 3992 increase & $20.23315 \%$ increase \\
\hline 2021 & 30865 & 7143 increase & $30.11129 \%$ increase \\
\hline 2022 & 35287 & 4422 increase & $14.32691 \%$ increase \\
\hline
\end{tabular}

During the first year of this study i.e. 2014 the total numbers of Nature-Wise Report of the Complaints Received by NCW was 33906 . During the second year of this study i.e. 2015 the total numbers of Nature-Wise Report of the Complaints Received by NCW were 23370 which is a decrease by $\mathbf{3 1 . 0 7 \%}$ compared to 2014. In the third year of this study i.e. 2016 the total numbers of Nature-Wise Report of the Complaints Received by NCW were 19088 which is a decrease by 18.32\% compared to 2015. For the year 2017 the total numbers of Nature-Wise Report of the Complaints Received by NCW were 14591 which is a decrease by 23.56\% compared to 2016. For the year 2018 the total numbers of Nature-Wise Report of the Complaints Received by NCW were 19908 which is an increase by $\mathbf{3 6 . 4 4 \%}$ compared to 2017. Just before the pandemic era i.e. 2019 the Complaints Received by NCW were 19730 which is a slight decrease by $\mathbf{0 . 8 9 \%}$ compared to 2018 (table-1, Fig. 1).

During the first year of pandemic i.e. 2020 the total numbers of Nature-Wise Report of the Complaints Received by NCW was 23722 which is an increase by $\mathbf{2 0 . 2 3 \% ~ c o m p a r e d ~ t o ~ 2 0 1 9 . ~ D u r i n g ~ t h e ~ s e c o n d ~ y e a r ~ o f ~ p a n d e m i c ~ i . e . ~} 2021$ the total numbers of Nature-Wise Report of the Complaints Received by NCW was 30865 which is an increase by $\mathbf{3 0 . 1 1 \%}$ compared to 2020 . During the third year of pandemic i.e. 2022 the total numbers of Nature-Wise Report of the Complaints Received by NCW is forecasted to be 35287 which is an increase by $14.32 \%$ compared to 2021 (table-1, Fig. 1).

Table 1 and Fig. 1 shows that the numbers of complaints were declining after 2014 with minimum complaints registered during 2017 . From year 2017 there is a trend of increase in complaints of violence which decreased in $\mathbf{2 0 1 9}$ before pandemic year $\mathbf{2 0 2 0}$. The prevalence of violence complaints get fuelled during covid-19 pandemic years by various situations and started increasing again from 2020 and expected to cross the 2014 numbers in 2022 as per projected data analysis. The author states that this is not necessary to happen if the covid-19 situation improves or if the government is deploying more resources and activities to control this violence against women pandemic in India. 
Table 2

- Total prevalence and top two complaints prevalence year-wise

\begin{tabular}{|c|c|c|c|}
\hline Nature & $\begin{array}{l}\text { Total } \\
\text { complaints }\end{array}$ & Female Population in different years & Prevalence per 100000 \\
\hline (2014) Total & 33906 & 621852998 & 5.452414012 \\
\hline Police Apathy against women (2014) & 7424 & 621852998 & 1.193851284 \\
\hline Right to live with dignity(2014) & 6950 & 621852998 & 1.117627481 \\
\hline 2015 Total & 23370 & 628929060 & 3.715840384 \\
\hline Police Apathy against women (2015) & 7016 & 628929060 & 1.115547118 \\
\hline Right to live with dignity (2015) & 6769 & 628929060 & 1.076274008 \\
\hline 2016 Total & 19088 & 635912563 & 3.00167053 \\
\hline Right to live with dignity (2016) & 5755 & 635912563 & 0.904998633 \\
\hline Police Apathy against women (2016) & 5543 & 635912563 & 0.871660716 \\
\hline 2017 Total & 14591 & 642796257 & 2.269926099 \\
\hline Right to live with dignity (2017) & 5023 & 642796257 & 0.781429566 \\
\hline Police Apathy against women (2017) & 2307 & 642796257 & 0.358900659 \\
\hline 2018 Total & 19908 & 649586703 & 3.064717906 \\
\hline Right to live with dignity (2018) & 7784 & 649586703 & 1.198300391 \\
\hline Dowry harassment / dowry death (2018) & 3245 & 649586703 & 0.499548403 \\
\hline 2019 Total & 19730 & 656288184 & 3.006301268 \\
\hline Right to live with dignity (2019) & 4694 & 656288184 & 0.715234574 \\
\hline Harassment of married women/Dowry harassment (2019) & 3883 & 656288184 & 0.591660812 \\
\hline 2020 Total & 23722 & 656288184 & 3.614570638 \\
\hline Right to live with dignity (2020) & 7715 & 656288184 & 1.175550648 \\
\hline Protection of Women against Domestic Violence (2020) & 5297 & 656288184 & 0.807114943 \\
\hline 2021 Total & 30865 & 670890572.9 & 4.600601237 \\
\hline Right to live with dignity (2021) & 11088 & 670890572.9 & 1.652728544 \\
\hline Protection of Women against Domestic Violence (2021) & 6684 & 670890572.9 & 0.996287661 \\
\hline 2022 Total & 35287.1 & 679672035 & 5.191785 \\
\hline Right to live with dignity (2022) & 13388.2 & 679672035 & 1.9698066 \\
\hline Protection of Women against Domestic Violence (2022) & 7310.02 & 679672035 & 1.07552118 \\
\hline
\end{tabular}

Table-3-Summary statistical analysis of total complaints, number of years, female population and prevalence

\begin{tabular}{|c|c|c|c|c|c|}
\hline \multicolumn{2}{|l|}{ Summary statistical analysis } & \multirow[b]{2}{*}{ Mean } & \multirow[b]{2}{*}{ Std. Dev. } & \multirow[b]{2}{*}{ Min } & \multirow[b]{2}{*}{ Max } \\
\hline Variable & Obs & & & & \\
\hline Year & 9 & 2018 & 2.738613 & 2014 & 2022 \\
\hline Total complaints & 9 & 24496.34 & 7233.145 & 14591 & 35287.1 \\
\hline Female Population in different years & 9 & $6.49 e+08$ & $1.90 e+07$ & $6.22 e+08$ & $6.80 e+08$ \\
\hline Prevalence of violence complain per 100000 & 9 & 3.768647 & 1.089161 & 2.269926 & 5.452414 \\
\hline
\end{tabular}

Table-4 - 


\begin{tabular}{|lllllll|}
\hline C/I means, summary & \multicolumn{2}{c}{} & & & & \\
Variable & Obs & Mean & & Std. Err. & [ 95\% Confidence Interval ] \\
\hline Year & 9 & 2018 & .9128709 & 2015.895 & 2020.105 \\
\hline Total complaints & 9 & 24496.34 & 2411.048 & 18936.46 & 30056.23 \\
\hline Female Population in different years & 9 & $6.49 \mathrm{e}+08$ & 6320113 & $6.35 \mathrm{e}+08$ & $6.64 \mathrm{e}+08$ \\
\hline Prevalence of violence complain per 100000 & 9 & 3.768647 & .3630537 & 2.931444 & 4.605851 \\
\hline
\end{tabular}

It is difficult to discuss all the nature of violence complaints in an article type of presentation, hence author is discussing little about top two violence complaints registered since 2014. For the years 2014 to 2017 the top two violence complaints are Police Apathy against women, Right to live with dignity whereas for the year 2018 it was Right to live with dignity, Dowry harassment / dowry death. For year 2019 the top two were Right to live with dignity, Harassment of married women/Dowry harassment. During the ongoing pandemic years 2020, 2021, 2022 the research study revealed that domestic violence related complain increased considerably making its place in top two after the complain related to right to live with dignity (see-table-2). The Prevalence of violence complain per 100000 female were 5.452414012, 3.715840384, 3.00167053, 2.269926099, 3.064717906, 3.006301268 3.614570638, 4.600601237, 5.191785 respectively for the years 2014 to 2022 respectively (see-table-2 and figure-2).

Table -3 and 4 shows that the mean Prevalence [95\% Confidence Interval - 2.931444-4.605851] of violence complain per 100000 during the period of study is 3.768647, Std. Dev. 1.089161, min. Prevalence of violence complain per 100000 is 2.269926 (year-2017) and max. Prevalence of violence complain per 100000 is 5.452414 (year-2014). The mean Total complaints [95\% Confidence Interval - 18936.46-30056.23] of total 09 years of observation are 24496.34, Std. Dev 7233.145, min. Total complaints during study period was 14591(2017) and maximum 35287.1 (year-2022).

Hence it is concluded from the above observation research study that the complaints of violence against women in India have increased in covid-19 pandemic era as compared to immediate years of pre-pandemic era except 2014. The maximum number of complain received in all the nine years of observation is of Right to live with dignity and the covid-19 pandemic era second year i.e. 2021 have maximum numbers of such Complaints Received by NCW (see Table 2). Protection of Women against Domestic Violence is next to the above mentioned complain during covid-19 pandemic era.

\section{Discussion}

This research study revealed that there was a declining trend of complaints of violence against women after 2014 up to 2017 (figure-2). After 2017 the trend changed and except for slight decrease in 2019 it increased continuously and projected to be maximum in the end of 2022 . Notably during the covid-19 pandemic years there is a steep increase in domestic violence making it in top two most registered violence complaints. Right to live with dignity related complaints of violence is at the top.

In the year 1983, domestic abuse/ violence was categorized under criminal offence in India. Mere punishment and imprisonment of the culprits is not enough to say that justice has been delivered. Recovery and rehabilitation of the victim to be able to lead a productive normal life should be the key goal. The Crime rate in India reported by the National Crime Records Bureau (NCRB) says that crime against women occurs at the rate of one crime against women per 1.7 minutes, and domestic abuse/violence at rate of one per 4.4 minutes [10]. During lock down women may be subjected to mental-psychological abuse like threats of being abandoned, demeaning, belittlement and insults and threats of hurting their loved ones, babies or increased general infidelity of the husband. The moral-psychological effects on physical-mental health due to abuse are more deep-seated in the brain and unrealized. Usually domestic abuse victims report with depression and PTSD (post traumatic stress disorder). Violence led depression in abused women can be chronic and has a life-long effect on the victim even in the absence of abuse for a long time. Several working women have lost their jobs during the covid-19 pandemic and sources of earning, which can lead to the loss of empowerment that these women had earlier [11].

Illiterate women may not have knowledge to reporting system as well as women from poor background with remote village areas with less communication mechanisms. The World Health Organization published that one-fourth of women between age 15-49 years have been in a relationship and subjected to physical and/or sexual violence at least once in their lifetime (since age 15). According to the WHO (World Health Organization), the prevalence of lifetime intimate partner related violence range is about $20 \%$ in Western Pacific, $22 \%$ in high-income countries and Europe (HIC) and $25 \%$ in WHO Americas Regions, $33 \%$ in WHO African region, $31 \%$ in WHO Eastern Mediterranean region, and like American region 33\% in the WHO South-East Asia region. $38 \%$ of women murders are committed by intimate partners as per WHO reports, as well as regarding partner violence, worldwide $6 \%$ of women report to be sexually harassedassaulted by someone other than a partner, although the WHO found that data for non-partner sexual violence are more limited. The Intimate partners as well as sexual violence are mostly found to be perpetrated by men against women [5].

Limitations and Strength of the research study

The author would like to make it clear that the complaints of violence are matters of investigation by police department and other concerned authorities. The author already stated in this article that actual acts of violence complaints are not being registered by everyone who suffers due to several reasons. Hence the secondary data obtained and projected may only represent the iceberg of violence complaints and the real number of such complaints may be several times bigger due to under-reporting as well as unable to report by the victims. The author confirms that more research and analysis with field investigation in real is required to get full scenario and answer to the research question mention in the title of this research study. The author has found several studies related to violence against women but this is a unique study in doing research over complaints of violence. The data is from an accredited source is one of the strength 
of the research study. More research with primary data collection is needed for better understanding of causality and association of complaints of violence against women.

Funding - The author has not received any fund for this research study from any sources.

\section{LAWS DEALING WITH DOMESTIC VIOLENCE IN INDIA}

There are several laws in the constitution of India which ensure protection of woman from being abused by anyone. Discussing laws is beyond the scope of this article. Since there is an exceptional increase in complaints of domestic violence a little discussion is presented by the authors regarding section $498 \mathrm{~A}$ IPC.

\section{SECTION 498A OF INDIA PENAL CODE}

As per section 498A IPC, if a woman's is subjected to any kind of harassment by husband or his relatives or if there is any act of cruelty against her, the culprits will be liable for imprisonment up to 03 years as well as monetary fine. Cruelty under the same section is stated as any act leading to compulsion for dowry demands from the woman or her family members or any act that forces the woman to commit suicide or inflict grievous injury upon herself (mental or physical)[12].

\section{PROTECTION OF WOMEN FROM DOMESTIC VIOLENCE ACT 2005-PWDVA}

The PWDVA (Protection of Women from Domestic Violence Act) 2005 is an Act passed by the Parliament of India and enacted to protect women from domestic abuse/violence. It was brought into force on 26 October 2006 by the Indian government and MoWCD (Ministry of Women and Child

Development). 2005-PWDVA prohibits a broad range of sexual, mental, physical, and economic violence against women. This Act also includes women in a live-in relationship as well. Under this Act, a woman has the full right to be free from abuse and can choose herself from different recourses. Act provides the right to get a restrictive order against her husband and his relatives, to be able to continue living in the same house, to claim maintenance, to have custody of her children and to claim compensation and to not be terrified out of her marital home[13].

\section{FAMILY COURT ACT, 1984}

Law Commission $59^{\text {th }}$ report laid significance on the establishment of distinct courts for matrimonial, personal and family issues, for speedy disposal of matrimonial and personal issues pending in civil and criminal courts [14].

\section{Conclusion And Recommendation}

India should make strategies for ensuring safety of women in such pandemic like situations. It seems present laws and regulations are insufficient. The barriers of legal-protective system and delivery of services constraints should be rectified. India should develop an exclusive plan for establishment of cadre of worker for women protection services. India is having huge women's population vulnerable to violence so the Government must give top priority in making India a safe place for women's. The violence have a serious impact on mental health especially in pandemic and lockdown situations in which its difficult to get help and relief. The COVID-19 pandemic seems to worsen the situation of the violence against women in India. The migrant women walked several miles due to lockdown strategy, some with their children in pregnancy, without availability of basic amenities like water, food etc. Due to the pandemic, about half a billion women are at risk of violence in India. Special policy or detailed COVID care plan for this special vulnerable group should be framed by the government to control the situation.

- Establishment of special women protection cell at central level as well as at all the states and union territories of India.

- gender equity in society

- Women constitute a large portion of population. Country must have a separate department to ensure protection to this vulnerable section of the population.

- India, the second most populous country in the world should have a robust women protection strategy to operate in any situations.

- The issue of mental health as well as socio-economic impacts of violence and lockdown should be properly taken care in pandemic like situation to protect women as well as their children.

\section{Declarations}

Note: - This article is available only as pre-print and not published by any peer-reviewed journals. The author has written previously on this research but this research study is unique and different from previous research of author. There are chances of text and data overlapping with my previous works available as preprints are mentioned below in the references $[15,16,17,18,19,20,21,22,23$, and 24].

-This version of paper has not been previously published in any peer reviewed journal and is not currently under consideration by any journal. The document is Microsoft word with English (United States) language \& 4583words (excluding reference-declaration) (5086 words Total).

- Ethics approval and consent to participate: Not applicable. This study has not involved any human or animals in real or for experiments.

-Consent for publication: The authors provide consent for publication.

-Availability of data and materials: Electronic records from National Commission for Women, World Bank

Page $9 / 12$ 
http://ncwapps.nic.in/frmComp_stat_Overview.aspx - NCW

https://data.worldbank.org/indicator/SP.POP.TOTL.FE.ZS?locations=IN - The world Bank- for female population data- projected up to 2022 with previous data using excel

-Conflicts of Interest/ Competing Interest: There are no conflicts / competing of interest

Funding-Self sponsored. No aid taken from individual or agency etc.

- Authors' contributions: The whole work is done by the Author - Dr Piyush Kumar, M.B.B.S., E.M.O.C., P.G.D.P.H.M., -Senior General Medical Officer- Bihar Health Services- Health Department- Government of Bihar, India and Advocate Anupama, Senior Lawyer, Bihar, India.

Acknowledgements- I am thankful to Advocate Anupama my wife and daughters Aathmika-Atheeva for cooperation.

- Author information: The author is currently working as Senior General Medical Officer for the government of Bihar, co-author is senior lawyer.

-Financial Support \& sponsorship: Nil

-Author contact information

Department of Health, Government of Bihar, MOBILE - +919955301119/+917677833752, Email drpiyush003@gmail.com

\section{References}

1. THE UNITED NATIONS WORK ON VIOLENCE AGAINST WOMEN - Available at https://www.un.org/womenwatch/daw/news/unwvaw.html

2. THE UNITED NATIONS -policy-brief-the-impact-of-covid-19-on-women-en-1.pdf - Available at https://www.un.org/sexualviolenceinconflict/wpcontent/uploads/2020/06/report/policy-brief-the-impact-of-covid-19-on-women/policy-brief-the-impact-of-covid-19-on-women-en-1.pdf

3. THE WORLD BANK -WOMEN'S VOICE, AGENCY, \& PARTICIPATION RESEARCH SERIES 2013 NO.3 - Duvvury et al. 2013 Intimate Partner Violence. Economic costs Available at

- https://www.worldbank.org/content/dam/Worldbank/document/Gender/Duvvury\%20et\%20al.\%202013\%20Intimate\%20Partner\%20Violence.\%20Economic\%

4. Direct and indirect effects of the COVID-19 pandemic and response in South Asia - Available

at https://www.unicef.org/rosa/media/13066/file/Main\%20Report.pdf

5. COVID-19 and violence against women - https://www.who.int/publications/i/item/WHO-SRH-20.04 World Health Organization

6. THE UNITED NATIONS - What Is Domestic Abuse? Available at https://www.un.org/en/coronavirus/what-is-domestic-abuse

7. WHO Director-General's opening remarks at the media briefing on COVID-19 - 11 March 2020 - Available at https://www.who.int/directorgeneral/speeches/detail/who-director-general-s-opening-remarks-at-the-media-briefing-on-covid-19--11-march-2020

8. Andrews, M. A., Areekal, B., Rajesh, K. R., Krishnan, J., Suryakala, R., Krishnan, B., Muraly, C. P., \& Santhosh, P. V. (2020). First confirmed case of COVID-19 infection in India: A case report. The Indian journal of medical research, 151(5), 490-492. https://doi.org/10.4103/ijmr.IJMR_2131_20

9. WHO- Coronavirus disease (COVID-19) advice for the public: Advocacy- available at - https://www.who.int/emergencies/diseases/novel-coronavirus2019/advice-for-public/healthy-parenting

10 Crime in India 2018, Statistics, 1 NCRB (2018), https://ncrb.gov.in/sites/default/files/Crime\%20in\%20lndia\%202018\%20-\%20Volume\%201.pdf.

11. International Labour Organization - available at - https://www.ilo.org/global/about-the-ilo/newsroom/news/WCMS_813449/lang-en/index.htm

12. Indian Code - Digital repository of all central and state acts, available at - https://www.indiacode.nic.in/show-data?

actid=AC_CEN_5_23_00037_186045_1523266765688\&sectionld=46286\&sectionno=498A\&orderno=562

13. Legislative department - Government of India - available at - https://legislative.gov.in/actsofparliamentfromtheyear/protection-women-domesticviolence-act-2005

14. Indian Code - Digital repository of all central and state acts, available at - https://www.indiacode.nic.in/handle/123456789/1844? view_type=browse\&sam_handle=123456789/1362

15. Author own preprints - Impact of Covid-19 pandemic on Prevalence of violence against women complaints in India - A cross-sectional comparative research study from 2014 to 2022? Available at - https://www.cambridge.org/engage/coe/article-details/6204bc88bd05a0a82201dabc

DOI- https://doi.org/10.33774/coe-2022-5jsqs Kumar, P., \& Anupama, A. (2022). Impact of Covid-19 pandemic on Prevalence of violence against women complaints in India - A cross-sectional comparative research study from 2014 to 2022? Cambridge Open Engage. doi: 10.33774/coe-2022-5jsqs This content is a preprint and has not been peer-reviewed. 
16. Author own preprints- DR PIYUSH KUMAR. (2022). What impact have Covid-19 pandemic era on violence against women in India - A retrospective comparative research study from January 2018 to December 2021. Qeios. doi:10.32388/M94VNI. https://doi.org/10.32388/M94VNI

17. Author own preprints- Kumar, Piyush and Kumar, Piyush and Anupama, Advocate, What Impact Have COVID-19 Pandemic Era on Violence against Women in India - A Retrospective Comparative Research Study from January 2018 to December 2021 (January 22, 2022). Available at SSRN: https://ssrn.com/abstract=4015482 or http://dx.doi.org/10.2139/ssrn.4015482

18. Author own preprints Kumar, D. (2022, January 14). What impact have Covid-19 pandemic era on violence against women in India - A retrospective comparative research study from January 2018 to December 2021. https://doi.org/10.31219/osf.io/f8hje

19. Author own preprints Dr Piyush Kumar, Advocate Anupama. What impact have Covid-19 pandemic era on violence against women in India - A retrospective comparative research study from January 2018 to December 2021, 14 January 2022, PREPRINT (Version 2) available at Research

Square https://doi.org/10.21203/rs.3.rs-1256722/v2

20. Author own preprints Dr Piyush Kumar, Advocate Anupama. What impact have Covid-19 pandemic era on violence against women in India from January 2020 to December 2021- A Retrospective comparative research study, 13 January 2022, PREPRINT (Version 1) available at Research

Square https://doi.org/10.21203/rs.3.rs-1256722/v1

21. Author own preprints Kumar, D. (2022, January 13). What impact have Covid-19 pandemic era on violence against women in India from January 2020 to December 2021- A Retrospective Research study. https://doi.org/10.31219/osf.io/547yw

22. Author own preprints Kumar DP. What Impact Have SARS-CoV-2/COVID-19 Pandemic on Domestic Violence against Women in India across Different States and Union Territories from the Beginning of Lockdown Due to COVID-19 Pandemic in March 2020 Till 20Th September 2020? How COVID-19 Pandemic Induced Lockdown Influence Mental Health of Women in India?. SSRN; 2021. DOI: https://doi.org/10.2139/ssrn.3826837

23. Author own preprints Dr Piyush Kumar. What Impact Have SARS-CoV-2/Covid-19 Pandemic on domestic violence against women in India across different states and union territories from the beginning of lockdown due to covid-19 pandemic in March 2020 till 20th September 2020? How Covid-19 pandemic induced lockdown influence mental health of women in India?, 14 April 2021, PREPRINT (Version 2) available at Research Square https://doi.org/10.21203/rs.3.rs-414848/v2 https://doi.org/10.21203/rs.3.rs-414848/v1

24. Author own preprints Kumar, D. (2021, April 12). What Impact Have SARS-CoV-2/Covid-19 Pandemic on domestic violence against women in India across different states and union territories from the beginning of lockdown due to covid-19 pandemic in March 2020 till 20th September

2020?. https://doi.org/10.31219/osf.io/7vgpx

\section{Figures}

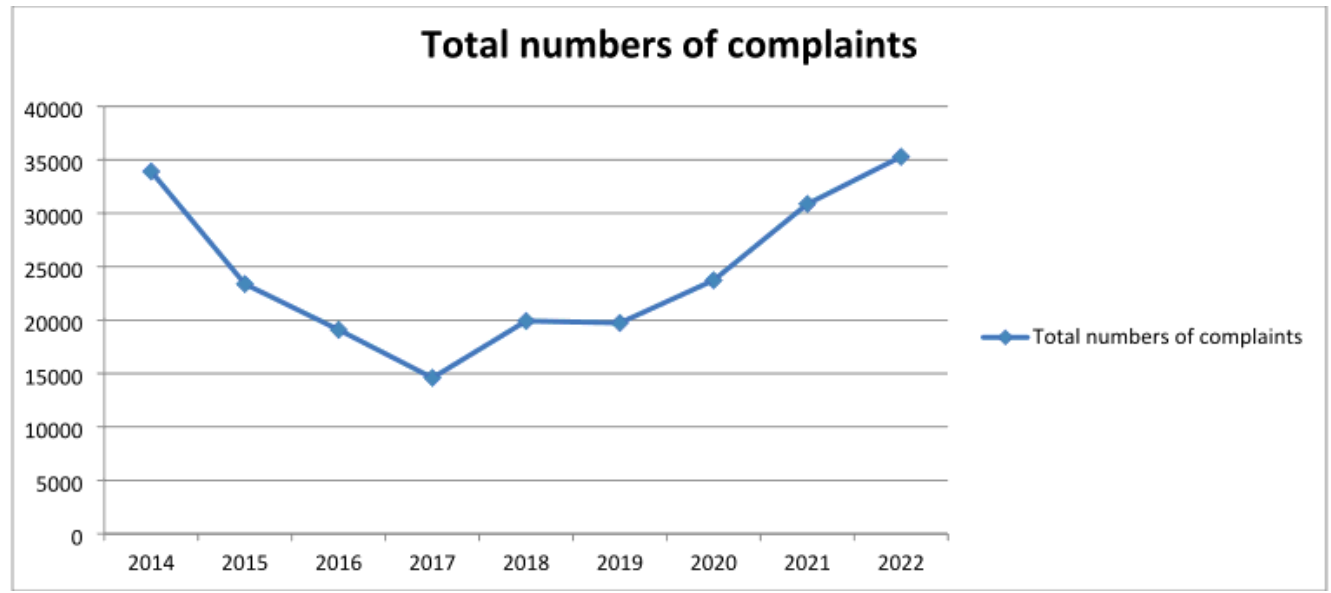

Figure 1

total numbers of complaints of violence against women received by NCW in different Year 


\section{Total Prevalence per 100000}

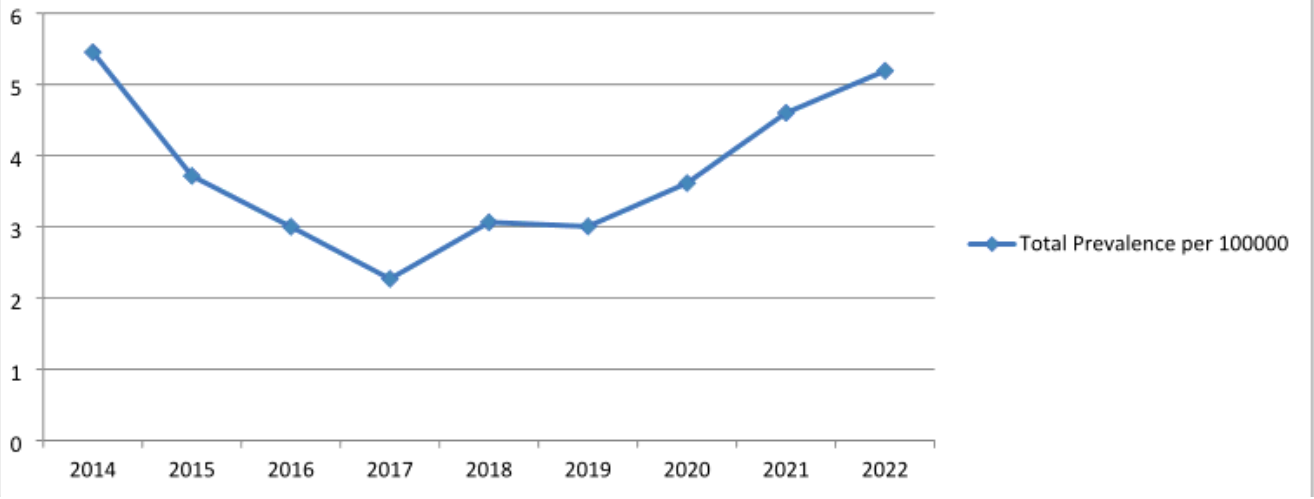

Figure 2

Total prevalence of complaints per 100000 female year-wise 